\title{
REINTERPRETASI MANTRA DALAM INSKRIPSI PENDEK CANDI SANGGAR
}

\author{
Reinterpretation Mantras of Short Inscriptions From Sanggar Temple
}

\author{
Rendra Agusta \\ Program Studi Kajian Budaya, Universitas Sebelas Maret \\ Jalan Ir. Sutami No. 36A, Jebres, Kota Surakarta, Jawa Tengah 57126 \\ E-mail: kangrendraagusta@gmail.com
}

Naskah diterima 14 September 2018 - Revisi terakhir 26 Otober 2018

Disetujui terbit 23 November 2018 - Tersedia secara online 30 November 2018

\begin{abstract}
The relation between archeology and philology studies is related to studies of relief and epigraphy. In the construction of the temple, it is usually followed by the carving of Javanese literary stories in the relief of temples in Java. During the period of Majapahit's political decline, there was an increase in the number of shrines in the mountains of Java. The end of Majapahit's power became an important time frame as a marker of the cultural transformations. This study will present a rereading of inscriptions at Candi Sanggar, a temple located on the slopes of Mount Bromo. The approach used in this research is Philoarchaeology. An archaeological perspective on artifacts and manuscripts. This research attempts to treat, describe, and interpret as text that reflects the supporting culture. Previous research, short inscriptions of Candi Sanggar only places as letters and languages. It is certainly open to other readings, putting its inscription as an arrangement of numbers or symbols. A less comprehensive study would lead to misinterpretation. So this paper places Candi Sanggar's short inscriptions in interpretation by considering philological studies, mainly on Budamtexts. This papper considers the paleographic study by aligning the Sanggar Temple inscriptions with the Merapi-Merbabu collection texts. The results of this study revealed that the short inscriptions at Sanggar Temple could be compared to the rules of Sengkalan Dihyang. The conclusions of Candi Sanggar inscriptions are Sengkalan Dihyang which reads 75 (1,3), 55 (3,5), 67 (3,3), 57 (3,2).
\end{abstract}

Keywords: Sanggar Temple, Bromo, Paleografi, Merapi Merbabu, Sakala Dihyang.

\begin{abstract}
Abstrak
Relasi antara kajian arkeologi dan filologi terkait dalam kajian-kajian relief dan epigrafi. Dalam pembangunan candi biasanya diikuti pemahatan kisah Sastra Jawa dalam relief candi-candi di Jawa. Proses pemahatan juga sejalan dengan pola kebudayaan di masa lampau. Pada masa kemunduran politik Majapahit, terjadi peningkatan jumlah pembangunan tempat suci di pegunungan Jawa. Akhir kekuasaan Majapahit menjadi rentang waktu yang penting sebagai penanda transformasi kebudayaaan. Penelitian ini menyajikan pembacaan ulang terhadap inskripsi di Candi Sanggar yang berada di lereng Gunung Bromo. Pendekatan yang digunakan adalah filoarkeologi, sebuah perspektif keilmuan yang menggabungkan metode arkeologi dan filologi. Penelitian ini berusaha memperlakukan, mendeskripsikan, dan menginterpretasikan teks yang merefleksikan kebudayaan pendukungnya. Penelitian terhadap inskripsi pendek Candi Sanggar hanya menempatkan inskripsi sebagai susunan huruf dan bahasa Jawa Kuna. Hal ini tentu membuka kesempatan untuk pembacaan lain, yakni menempatkan inskripsi sebagai susunan angka
\end{abstract}


atau simbol. Kajian yang kurang komprehensif tentu menyebabkan terjadinya salah tafsir. Oleh sebab itu, tulisan ini menempatkan inskripsi pendek Candi Sanggar dalam interpretasi dengan mempertimbangkan kajian-kajian filologis, utamanya pada naskah-naskah beraksara Buda. Penelitian ini menyejajarkan inskripsi Candi Sanggar dengan naskah-naskah koleksi MerapiMerbabu abad ke-16 sampai dengan abad ke-18. Hasil penelitian ini mengungkapkan bahwa inskripsi pendek di Candi Sanggar dapat disejajarkan dengan kaidah Sengkalan Dihyang. Simpulan inskripsi Candi Sanggar adalah Sengkalan Dihyang berbunyi 75 (1,3), 55 (3,5), 67 (3,3), dan 57 $(3,2)$.

Kata kunci: Candi Sanggar, Bromo, paleografi, Merapi Merbabu, Sakala Dihyang.

\section{PENDAHULUAN}

Studi Jawa Kuna selalu terpumpun dengan ilmu-ilmu serumpun. Studi ini terkait dengan berbagai ilmu pendukungnya, baik sejarah, linguistik, sastra, filologi, arkeologi, maupun ilmu lainnya. Utamanya dalam studi paleografi, penelitian epigrafi dan filologi pasti akan selalu berkorelasi.

Perkembangan aksara di Indonesia melampaui beberapa zaman, mulai dari era Kerajaan Tarumanagara hingga masa kini. Aksara sebagai wujud kebudayaan, tentunya tidak dapat dikaji melalui satu sudut pandang keilmuan. Hal ini memungkinkan adanya persinggungan antara studi arkeologi, utamanya epigrafi dengan filologi. Pendekatan komprehensif antara epigrafi dengan objek kajian prasasti dan filologi dengan teks disebut dengan filoarkeologi (Dwiyanto, 2018: 35). Pandangan tersebut didahului oleh A.J. Berneth Kempers yang menyatakan bahwa perbedaan kajian epigrafi dan filologi hanya terletak pada objek. Objek kajian arkeologi pada umumnya terletak di dalam tanah, sedangankan kajian filologi berada di atas tanah (Kempers, 1941).
Keduanya bertujuan untuk merekonstruksi (baik teks maupun bangunan) agar diketahui segala fungsinya dalam bingkai kebudayaan di masa lampau. Dengan demikian, kajian epigrafi dan filologi sangat dekat hubungannya, sebagai ilmu bantu untuk ilmu lainnya.

Ada beberapa kajian yang membuktikan relasi antara kajian arkeologi dan filologi saling berdampingan, antara lain dalam pembangunan Candi Prambanan, relief cerita yang berangkat dari kisah Bhattikavya (Zoetmulder, 1994: 290); kisah tantri (Zoetmulder, 1994); cerita panji (Zoetmulder, 1994), dan beberapa kisah lain yang semua diabadikan dalam relief candi-candi di Jawa. Proses pemahatan ini juga sejalan dengan pola kebudayaan di masa lampau, tidak sedikit pemilihan cerita yang ditampilkan sangat berbeda dengan versi mayoritas. Kadang-kadang pemilihan sangat fragmentaris dan parsial (Munandar, 2004). Secara khusus studi aksara Jawa Pertengahan dapat disejajarkan keberadaan dengan prasastiprasasti di akhir Majapahit dan karya Sastra Jawa Tengahan. Akhir kekuasaan 
Majapahit menjadi rentang waktu yang penting sebagai penanda transformasi kebudayaan. Pada masa kemunduran politik, terjadi peningkatan jumlah pembangunan tempat suci di pegunungan Jawa (Kieven, 2017: 19). Banyak aktivitas religius di area pegunungan, hal ini menyebabkan pembangunan ritus tidak lagi memperhatikan arah angin, tetapi cenderung kembali pada alam, seperti gunung. Beberapa kawasan yang mencatat aktivitas religiusitas tersebut, antara lain Kawasan Bromo-TenggerSemeru (Hefner, 1992: 267), ArjunaWelirang-Penanggungan (Munandar, 1990), dan Merapi-Merbabu (Molen, 2011: 140). Secara khusus, satu-satunya candi yang berada di lereng Gunung Bromo pernah dikaji Balai Arkeologi Yogyakarta, yaitu Candi Sanggar (Istari, 2006). Penelitian ini dilakukan pada tahun 2005 dan 2006 dengan judul "Arsitektur dan Latar Belakang Pendirian Candi Sanggar di Lereng Gunung Bromo". Penelitian tersebut mengungkapkan bahwa Candi Sanggar merupakan tempat pemujaan kepada Dewa Brahma dan salah satu inskripsi pendeknya merupakan puji-pujian kepada Brahma (Istari, 2015: 51-62). Penelitian terhadap inskripsi pendek Candi Sanggar tersebut hanya menempatkan inskripsi sebagai susunan huruf Jawa Kuna dan berbahasa Jawa Kuna. Hal inilah tentu membuka untuk pembacaan lain, yakni menempatkan inskripsi sebagai susunan angka atau simbol. Hal ini yang menyebabkan terjadinya salah tafsir. Oleh sebab itu, tulisan ini menempatkan inskripsi pendek Candi Sanggar dalam interpretasi dengan mempertimbangkan kajian-kajian filologis, utamanya pada naskah-naskah beraksara Buda ${ }^{1}$. Naskah beraksara Buda ini tersebar di Kabuyutan Ciburuy di Kabupaten Garut, Kawasan Merapi-Merbabu, dan masyarakat Tengger. Naskah-naskah beraksara Buda ini dimungkinkan sebagai perkembangan aksara Jawa Kuna dengan media yang lain.

Fokus penelitian adalah inskripsi pendek Candi Sanggar di Kawasan Bromo. Pendekatan yang digunakan dalam penelitian ini adalah filoarkeologi, yakni penelitian dengan perspektif arkeologi terhadap artefak dan naskah, berusaha memperlakukan, mendeskripsikan, dan menginterpretasikan teks yang merefleksikan kebudayaan pendukungnya. Hal ini sejalan dengan Pidato Pengukuhan Guru Besar Ilmu Sastra, UGM, Sulastin Sutrisno. Dalam pidato yang berjudul "Relevansi Studi Filologi" disebutkan bahwa salah satu bidang ilmu yang relevan dengan filologi adalah arkeologi, terutama karena salah satu pengertian ahli filologi (filolog) adalah ahli purbakala teks melalui huruf, kata-kata, dan kalimat yang ditemukannya (Sutrisno, 1981). Penelitian ini dimulai dengan merumuskan permasalahan yang berawal dari adanya fenomena arkeologis yang

\footnotetext{
${ }^{1}$ Istilah aksara Buddha pertama kali dikenalkan oleh Pigeaud (1970) pada bukunya Literature of Java. Maksud kata Buddha bukan berarti agama, tetapi lebih dalam konteks di luar agama Islam atau kepercayaan lokal.
} 
harus dikaji atau dianalisis berdasarkan studi terhadap naskah-naskah dan teksnya. Lalu, melakukan pencarian dan pencatatan sumber-sumber tertulis, dalam hal ini segenap naskah yang diperlukan untuk menjawab rumusan masalah: mengungkap fakta-fakta (teks) dari naskah yang relevan dengan rumusan permasalahan. Setelah itu, dilakukan eksplanasi atau menghubungkan dan menerangkan jalinan atau keterkaitan antara fakta-fakta arkeologis dengan fakta-fakta filologis.

\section{PEMBAHASAN}

Candi Sanggar terletak di Dusun Wonogriyo, Desa Pusungmalang, Kecamatan Puspo, Kabupaten Pasuruan, Jawa Timur. Candi ini berada di koordinat $07^{\circ} 50^{\prime} 57,8^{\prime \prime}$ LS dan $112^{\circ} 56^{\prime} 36,5^{\prime \prime}$ BT, dengan ketinggian 1.340 mdpl, di lereng Gunung Penanjakan (salah satu anak Gunung Bromo). Pada desa ini telah ditemukan candi berbahan batu andesit, diperkirakan seluas $500 \mathrm{~m}^{2}$. Candi berbentuk punden berundak tersebut terdiri dari tiga halaman, diperkirakan berasal dari masa Hindu-Buddha. Konsep candi pemujaan di gunung ini dapat jumpai pula di Candi Cetho dan Sukuh, lereng barat Gunung Lawu, peninggalan karesyan Pawitra di Gunung Penanggungan. Tempat-tempat ini adalah mandala sekaligus permukiman kaum agamawan pada masa tersebut. Menurut Munandar (2013: 17), kaum resi dan pertapa pada masa Majapahit sangat mungkin memuliakan tokoh (1) Siwa, (2) Buddha, (3) Siwa-
Buddha, (4) Parwatarajadewa (dewa penguasa gunung), (5) arwah leluhur yang didewakan, serta (6) tokoh dewata lainnya. Penelitian Candi Sanggar dimulai dari adanya laporan dari Sukarno B.A., seorang mantan Kepala Sekolah Dasar Bulukambang II, Lumbang, Pasuruan. Pada tahun 2005 dan 2006 Balai Arkeologi Yogyakarta memulai penelitian dan menyatakan bahwa Candi Sanggar merupakan tempat pemujaan kepada Brahma. Catatan Kartadiwirya (1932:14) secara detail menjelaskan ada dua puluh satu aspek yang dipuja oleh masyarakat Tengger, yakni Pangeran Ingkang Mahakuwasa, Dewa Wisnu, Brahma, Kala, Lodra, Sang Hyang Guru, Sanggar, Danyang, Batara Suci Sewaya, Bapa Kasa, Ibu Pertiwi, Maha Inten, Anggana-Angginim Kaki Pundhutan, Kaki Pekik, Kaki Pangingkih, Kaki Pangitan, Dewa Lang-Lang Buwana, Kaki Nini Citragota, Dewa Panyarikan, dan penghuni alam lainya. Segala aspek arkeologis terkait tata ruang, struktur, dan fungsi candi ini cukup banyak dibahas dalam laporan penelitian Balai Arkeologi Yogyakarta, secara umum sepakat dengan kajian tersebut. Oleh karena itu, secara khusus pembahasan difokuskan (Kartadiwirya, 1932)pada kajian paleografi, baik epigrafi maupun filologi.

Dalam Kamus Besar Bahasa Indonesia (2008: 558), inskripsi berarti kata-kata yang terukir pada batu, monumen, atau dicap pada uang logam, medali, dan piala. Sementara itu, prasasti biasanya dikeluarkan oleh raja-raja yang dipahatkan pada batu besar yang berisi 
puji-pujian, ancaman, kekuasaan, sima, dan pasek-pasek. Berdasarkan perbedaan kedua arti tersebut, inskripsi cenderung pendek dan hanya terdiri dari satu atau dua kata, kalimat pada prasasti cenderung panjang. Oleh karena itu, dapat saja inskripsi dibuat oleh orang biasa yang kurang mengetahui gramatika bahasa Sansekerta atau Jawa. Fungsi dari inskripsi pendek antara lain digunakan untuk menyebut nama-nama dewa yang dipuja, angka tahun, dan nama-nama pembuat. Penggunaan inskripsi pendek sebelumnya dapat ditemukan pada penelitian terkait inskripsi pendek di relief Karmawibangga Candi Borobudur (Ashari, 2010), pembacaan inskripsi pendek di Candi Plaosan (Boechari, 2012: 128), dan inskripsi pendek di Gunung Penanggungan (Munandar, 1990).

Pembangunan Candi Sanggar diasumsikan secara bertahap, berlangsung antara abad ke-14 sampai dengan abad ke-16 Masehi. Hal ini dibuktikan dengan ditemukannya inskripsi pendek dalam batu andesit beraksara Jawa Kuna yang berisi tahun (Istari, 2015: 64) antara lain (1) 1267 Saka atau 1345 Masehi, (2) 1431 Saka atau 1509 Masehi, (3) Suryasengkala rupa guna catur janma yang diartikan 1431 Saka atau 1509 Masehi (Bratakesawa, 1980). Berdasarkan angka tahun 1431 Saka atau 1509 Masehi, Candi Sanggar setidaknya didirikan atau dibangun kembali pada era akhir Majapahit ketika diperintah Girindrawarddhana Dyah Ranawijaya Bhattāra i Kling. Ia memerintah antara tahun 1396--1441 Saka atau 1474--1519 Masehi.

Pada tahun 1932 seorang guru Injil bernama M. Prasman Kartadiwirya membuat laporan penginjilan di masyarakat Tengger. Catatan tersebut juga memuat kehidupan masyarakat Tengger dari sejarah, mitos, kepercayaan, tata rumah, tata ritual, dan lain-lain. Pada catatannya banyak disebutkan desa-desa di bawah Distrik Tengger, baik di Pasuruan, Probolinggo, maupun Malang. Desa-desa tersebut antara lain Wanakerta, Ngados, Djetak, Wanatara, Ngadisari, Ngados Malang, Ngadiwana, Tosari, Sedaeng, dan Wonokitri (Kartadiwirya, 1932: 2). Berdasarkan desa-desa yang disebutkan dalam catatan tersebut, tidak menutup kemungkinan Prasman juga sampai di Candi Sanggar (Wonogriyo). Pada halaman sepuluh dijelaskan adanya keterangan Sanggar. Sanggar adalah batu yang didirikan dengan ritual ruwatan dengan menyembelih dua ekor kerbau atau lebih yang terletak di tengah desa atau kemungkinan diletakkan di daerah tertinggi di desa ${ }^{2}$. Dalam keterangan bagian kepercayaan tersebut terdapat sketsa angka tahun di tengah-tengah sketsa makhluk halus yang dipuja oleh masyarakat Tengger. Sketsa tersebut beraksara Jawa Kuna yang menunjukkan angka 1267 Saka atau 1345 Masehi. Selama penelitian, belum pernah ditemukan prasasti lain yang berangka

\footnotetext{
${ }^{2}$ Teks Asli: Sanggar inggih punika sela ingkang dipunadĕgaken sarana dipunruwat lan mragat maesa 2 utawi langkung, lajeng dipunpapanakěn ing těngah dhusun utawi ing sangingiling dhusun.
} 
1267 Saka di kawasan Tengger selain di Candi Sanggar sehingga dapat diasumsikan bahwa sketsa ini adalah catatan awal tentang keberadaan Candi Sanggar.

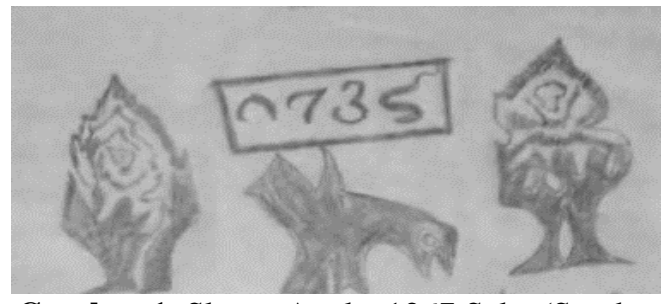

Gambar 1. Sketsa Angka 1267 Saka (Sumber: Dokumen Koleksi Perpustakaan Universitas Indonesia, Nomor AA. 38.03/FSUI LL33)

Selain inskripsi penanda tahun, juga ditemukan batu andesit bertuliskan pa dra dra dra a la dra la, ditafsirkan sebagai mantra pemujaan atau kutukan (Istari, 2014). Pada penelitian lanjutan Istari (2015: 64), pembacaan ulang inskripsi tersebut menjadi pa dra dra dra mu la dra la. Istari, menyebutkan bahwa kata mula berarti 'awal, asal mula, atau asli'. Selain itu, Istari berpendapat bahwa kalimat dalam prasasti itu ada hubungannya dengan asal mula suatu kehidupan dan ada sangkut pautnya dengan Dewa Brahma yang bersemayam di Gunung Bromo, sebagai dewa pencipta dalam kepercayaan agama Hindu(Istari, 2015: 65). Pada inskripsi tersebut juga terdapat bulat-bulatan kecil yang berjumlah 1, 2, 3, dan 5. Bulat-bulatan ini juga ditafsirkan sebagai nada-nada. Istari (Istari, 2015: 68) menambahkan bahwa bulatan tersebut dibaca dalam bahasa Jawa, yakni ji lu lu ma lu lu lu ra dengan cara dilagukan. Pada bagian simpulan ditegaskan bahwa prasasti pendek di
Candi Sanggar itu adalah mantra pemujaan kepada Dewa Brahma dengan cara ditembangkan. Simpulan yang diambil dalam penelitian Istari cukup menarik karena menghubungkan relief dengan sistem tembang dan mantra. Namun, salah satu hal yang penting tentunya fakta-fakta lain dari bidang filologis terkait naskah-naskah yang beraksara Buddha.

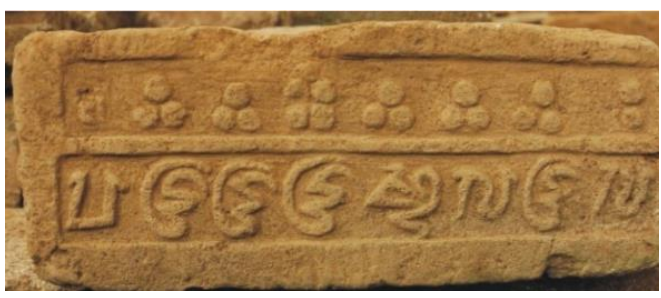

Gambar 2. Inskripsi Pendek di Candi Sanggar (Sumber: Dokumen Istari, 2006)

\section{Prasasti-Prasasti Bercorak Khusus}

Abad ke-15 merupakan masa kemunduran Majapahit. Berdasarkan inskripsi pada Candi Sanggar 1431 Saka atau 1509 Masehi, era ini adalah masa kemerosotan kekuatan Majapahit. Beberapa faktor menjadi alasan merosotnya kekuatan Majapahit. Kompleksitas permasalahan dari perang saudara, persaingan ekonomi, dan perubahan keagamaan secara masif terjadi di pantai utara Jawa. Pusat-pusat perdagangan internasional mulai dikuasai oleh kaum muslim dari Arab, India, dan Cina. Salah satu dampak dari kemunduran tersebut adalah Majapahit melakukan hubungan perdagangan independen dengan pedagang-pedagang di pesisir, berangsur-angsur kekuataan perdagangan maritim Majapahit menurun. Akhirnya, sisa-sisa kekuatan 
Majapahit terfokus pada pembangunan ekonomi di pedalaman, terutama pegunungan (Hall, 1985: 253). Pembangunan di pedesaan inilah kemudian yang menyebabkan peningkatan pembangunan tempat-tempat suci di pegunungan. Pada kisah Bujangga Manik yang ditulis pada abad ke-15 atau awal abad ke-16, diceritakan perjalanannya ke tempat-tempat suci di Jawa. Naskah tersebut juga menyebutkan Gunung Bromo datang $k a$ gunung Brahma dan Gunung Merbabu cunduk ti gunung Damalung sebagai salah satu gunung yang menjadi pusat pengajaran keagamaan Buddha (Noorduyn, 1982: 427). Salah satu yang merekam jejak perkembangan kebudayaan Jawa Kuna, utamanya aksara, adalah naskah-naskah skriptorium Merapi-Merbabu.

Kedekatan prasasti era Majapahit akhir dan naskah-naskah beraksara Buddha ini setidaknya terdapat pada gaya bahasa, bentuk huruf, dan pungtuasi. Prasasti bercorak khusus dapat dijumpai dalam sembilan belas prasasti, yaitu Prasasti Pasrujambe, Prasasti-prasasti Pawitra, Prasasti Widodaren, Prasasti Gerba, Prasasti Samirono, Prasasti Ngadoman (Damalung), Prasasti Ngrawan, Prasasti Sukuh, dan Prasasti Sine. Prasasti bercorak khusus ini dianggap sebagai penyimpangan atau gaya penulisan baru yang terkesan singkat, tebal, kaku, dan tidak anggun sama sekali. Casparis (1975: 65) menyatakan bahwa perkembangan tulisan di Jawa terus mengalami perkembangan hingga aksara modern, yang disebutnya dengan aksara Majapahit akhir. Berdasarkan beberapa prasasti bercorak khusus, ada dua jenis tulisan, yakni gaya tatah timbul dan gaya tatah ke dalam. Pada prasasti bercorak khusus ini ada beberapa yang mencantumkan tanggal kalender, yakni Prasasti Sukuh (1359, 1361, 1362, 1363, dan 1364 Saka $)^{3}$, Prasasti Surodakan 1369 Saka, Prasasti Samirono $1370 \mathrm{Saka}^{4}$, Prasasti Damalung 1371 Saka $^{5}$, Prasasti Ngrawan 1372 Saka $^{6}$, Prasasti Ungaran 1373 Saka $^{7}$, Prasasti Sine (1381 Saka $)^{8}$, Prasasti Pasrujambe V dan VII (1391 Saka) ${ }^{9}$, dan Prasasti-prasasti Pawitra ${ }^{10}$. Menurut van Romondt, sebagaimana yang dikutip Lutfi (2015: 17), Pawitra memiliki angka tahun yang paling muda, yakni 1433 Saka (1511 M). Hal ini memungkinkan di era yang sama dalam penggunaan aksara yang bercorak khusus tersebut. Pada beberapa prasasti akhir Majapahit, beberapa aksara memiliki persamaan

\footnotetext{
${ }^{3}$ Penelitian mengenai paleografi aksara di Candi Sukuh banyak dibahas Agung Bachtiar dalam skripsinya yang berjudul "Prasasti-Prasasti Candi Sukuh: Suatu Tinjauan Aksara dan Bahasa" Jurusan Arkeologi, Universitas Indonesia, 2012.

${ }^{4}$ Prasasti ini merupakan koleksi BPCB Jawa Tengah tertulis $i$ saka 1370.

${ }^{5}$ Kajian prasasti ini dapat dibaca dalam Bijdragen tot de taal-, land- en volkenkunde van Nederlandsch-Indië tahun 1872 halaman 271.

${ }^{6}$ Prasasti ini berada di Desa Ngrawan, Kecamatan Getasan, Kab. Semarang.

${ }^{7}$ Prasasti ini terletak di kawasan hutan Gunung Ungaran. Prasasti ini ditemukan kembali oleh Tri Subekso, Pamong Budaya Kabupaten Semarang. Pembacaan dibantu oleh Abimardha Kurniawan, Kandidat doktor Sastra di Universitas Indonesia.

${ }^{8}$ Prasasti ini dibahas R. Frederich dalam Tijdschrift Bataviaasch Genootschap tahun 1855 halaman 335--336.

${ }^{9}$ Prasasti ini dibahas M.M. Sukarto K. Atmodjo dalam Berkala Arkeologi VII tahun 1984 halaman 39--55.

${ }^{10}$ Prasasti di Gunung Penanggungan cukup banyak dibahas oleh Ismail Lutfi (Lutfi, 2015).
} 
dengan naskah-naskah beraksara Buda atau aksara Gunung. Kajian paleografis komprehensif tentang bentuk-bentuk aksara di masa Majapahit akhir belum juga usai, mengingat banyak naskah yang beraksara Buda yang tersebar di beberapa negara belum tuntas dikaji secara filologis.

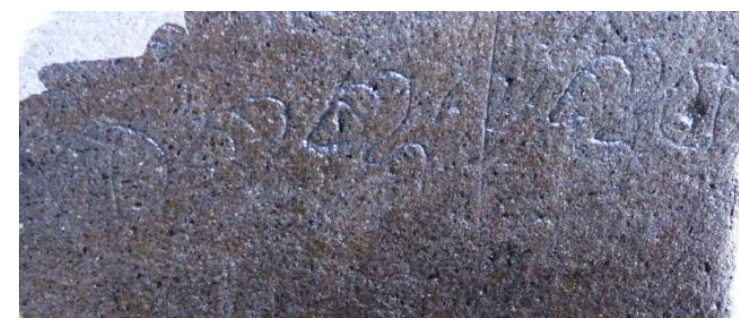

Gambar 3. Prasasti Ngrawan 1372 Saka

(Sumber: Dokumen Rendra Agusta, 2018).

Tradisi tulis di kawasan MerapiMerbabu dikenal setidaknya pada abad ke-16 hingga abad ke-18. Naskah-naskah dari kawasan tersebut sering disebut dengan koleksi Merapi-Merbabu. Hal ini disebabkan mayoritas penulisan naskahnaskah tersebut berada di Gunung Mandrageni (nama lama Gunung Merapi) dan Damalung atau Pamrihan (nama lama Gunung Merbabu). Ada hipotesis yang menyatakan bahwa penyalinan naskah ini dimulai pada era Mataram Kuna yang dilanjutkan sampai dengan masa Mataram Islam, Kartasura, Surakarta, dan Yogyakarta (Molen \& Wiryamartana, 2001: 51). Koleksi ini ditemukan di lereng Gunung Merbabu pada tahun 1820, milik seorang ajar bernama Windusana. Pada tahun 1852 naskah-naskah ini dibeli oleh Koninklijk Bataviaasch Genootschap van Kunsten en Wetenschappen, sekarang menjadi koleksi Perpustakaan Nasional Republik Indonesia (PNRI) (Molen, 2011: 135). Naskah berjumlah 357. 27 naskah ditulis dalam Aksara Jawa, 330 lainnya ditulis dalam aksara Jawa Kuna (Bleeker, 1852: $6)^{11}$. Menurut Katalog Naskah MerapiMerbabu (selanjutnya disebut MM), jumlah koleksi naskah MM di Perpustakaan Nasional RI sekitar 357 naskah (Setyawati, Molen, \& Martana, 2002). Sebagian besar aksara ditulis dalam naskah MM yang menurut Friederich, sebagaimana yang diacu Molen (2011), tulisan kuna itu disebut aksara Buda atau aksara Gunung. Dalam naskah bernomor KBG 208, halaman 8 disebutkan Punika aksara buda ingkang kaangge para ajar-ajar ing rĕdi ${ }^{12}$. Bentuk teks naskah MM berragam: parwa, kakawin, kidung, dan lain-lain. Beberapa koleksi MM yang pernah diteliti antara lain Kunjarakarna oleh Willem van der Molen tahun 1983 yang diterjemahkan dalam bahasa Indonesia (Molen, 2011), Arjunawiwaha oleh Martana (1990), dan Setyawati (2015). Penanggalan naskahnaskah MM belum banyak dikaji. William James Cohen Stuart berpendapat bahwa naskah-naskah MM berkisar antara abad ke-16 sampai abad ke-18, sedangkan Molen menyatakan setidaknya naskah MM berkisar antara abad ke-17 sampai dengan abad ke-18. Pendapat lain

\footnotetext{
${ }^{11}$ Bleeker, P. "Verzlag der werkzaamheden van het Bataviaasch Genootschap van Kunsten en Wetenschappen, van September 1850 tot April 1852, namens het bestuur des Genootschaps voorgelezen in de algemeene vergadering op den 27sten April 1852", Verhandelingen Bataviaasch Genootschap24, 1852.

${ }^{12}$ Terjemahan: ini aksara Buda yang di pakai para ajar di gunung-gunung.
} 
muncul dalam kajian Gita Sinangsaya, yang memuat epiteks tentang pembunuhan Pangeran Madiun, Wira Menggala, dan peristiwa meledaknya gudang mesiu karena perintah susuhunan. Berbagai perbandingan dari Babad Momana, Babad Sengkala, dan beberapa laporan kolonial setidaknya memberikan gambaran bahwa tarikh 1592 tahun MM sama dengan 1670 Masehi (Kurniawan, 2017: 1-29). Selisih 78 tahun ini setidaknya memberikan gambaran bahwa tahun 1592 MM pada naskah Gita Sinangsaya sama juga dengan 1592 Saka walaupun selisih ini tidak dapat digunakan sebagai acuan bagi naskah MM. Menurut Setyawati (1995: 36-39), penanggalan naskah MM biasanya terletak di awal atau akhir penulisan. Lebih lanjut dijelaskan bahwa sistem penanggalan naskah MM umumnya berupa penanggalan yang menyebutkan triwara, pasaran-pancawara, paringkelan-sad wara, hari-saptawara, wuku, dan sengkalan. Sengkalan adalah kronogram Jawa yang biasa digunakan untuk menerangkan angka tertentu dengan cara dihitung dari satuan ke ribuan (Bratakesawa, 1980). Sengkalan dalam naskah MM terbagi dalam empat jenis, yakni (1) Sěngkalan Mĕlok, (2) Sěngkalan Koci, (3) Sěngkalan Milir, dan (4) Sěngkalan Dihang atau Dihyang. Setyawati (2015: 143) menyebutkan, terdapat satu lagi jenis sengkalan, yakni Sengkalan Tërus, sengkalan kelima ini tidak banyak diketahui kegunaannya, perlu adanya penelitian lebih lanjut tentang sengkalan těrus ini. Sěngkalan mělok yang secara eksplisit menampilkan angka tahun ditemukan di naskah $\mathrm{F}$ dalam suntingan Kidung Surajaya yang berbunyi "i sakala mlok 8, 1, 61" (Setyawati, 2015: 454). Bentuk Séngkalan Koci berupa gambar bulatan sejumlah bilangan angka yang dimaksud. Misalkan pada gambar empat, dibaca dengan $8,1,6,1$, kemudian diartikan sebagai 1618 tahun MM.

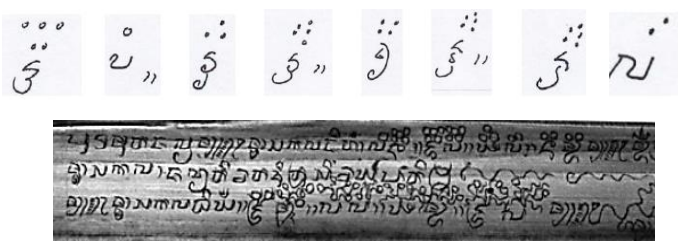

Gambar 4. Sengkalan Dihyang pada Naskah D Kidung Surajaya, (Bawah) Sengkalan Dihyang pada Naskah Gita Sinangsaya MM L 313 Lempir 38 Verso (Sumber: Dokumen koleksi Perpustakan Nasional, RI)

Sěngkalan Milir berupa susunan kalimat yang setiap bagian katanya menyiratkan angka, masyarakat Jawa kini biasa menyebutnya sěngkalan lamba. Contoh sengkalan ini dapat dijumpai dalam kajian Molen pada naskah $\mathrm{H}$ suntingan Kunjarakarna (Molen, 2011: 351). Penulisan dengan sengkalan milir: gana(6), sasi(1), hoyĕg(6), wulan(1); menyiratkan angka tahun $6,1,6,1$ dibaca: 1616 tahun MM. Akan tetapi, hal ini tampaknya tidak demikian, gana mungkin sebaiknya dibaca naga, seperti dalam kasus Kuñjarakarna. Sengkalan ini juga ditemukan dalam inskripsi Candi Sanggar yang berbunyi rupa (1), guna (3), catur (4), dan janma (1). Kata-kata ini menyiratkan 1, 3, 4, 1 yang dibaca 1431 
Saka atau 1509 Masehi. Selanjutnya, bentuk Sěngkalan dihang atau dihyang atau diyyang berupa kombinasi antara bulatan dan angka. Pada umumnya terdapat empat pasang angka yang masing-masing terdiri dari dua angka. Namun, antara jumlah bulan dan angka tidak sinkron. Untuk jenis sěngkalan ini belum ditemukan metode pembacaannya. Sebagai contoh dalam naskah Gita Sinangsaya (Kriswanto, 2012: 2012) L 313 pada lempir 38 verso terdapat jenis sengkalan yang berbunyi $i$ sakala dihang, 76(1,5), 47(1,0), 97(3,2), 62(2,2) dan $i$ sakala dmmn hiyang, 52(2,6), 77(6,4), 93(4,3), 57(3,2).
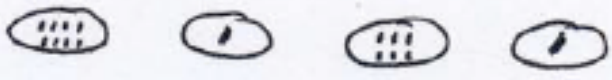

Gambar 5. Ilustrasi Sakala Koci (Sumber: Suntingan Kidung Surajaya oleh Kartika Setyawati, 2018).

Dengan berbagai pertimbangan paleografis dalam naskah-naskah koleksi MM, pembacaan inskripsi pendek di Candi Sanggar disarankan disejajarkan dengan kaidah Sěngkalan Dihang. Aksara dalam inskripsi Candi Sanggar sangat mirip dengan bentuk aksara naskah MM (bandingkan gambar 2 dan gambar 4). Inskripsi pendek Candi Sanggar

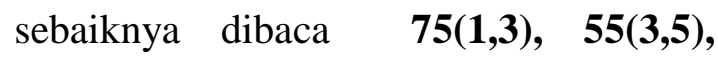
$67(3,3), 57(3,2)$.

\section{SIMPULAN}

Candi Sanggar adalah satusatunya tempat suci yang berada di kawasan Gunung Bromo. Seperti pada gunung-gunung lainya, pada masa akhir kekuasaan Majapahit terjadi pertarungan wacana, baik di bidang politik, ekonomi, maupun religius. Pertarungan wacana ini menyebabkan perubahan arus kebudayaan yang dapat dilacak dari artefak-artefak di masa itu. Aksara merupakan artefak penting penanda perubahan zaman, ketika pada abad ke16-18 terjadi perubahan corak aksara Jawa. Pada studi epigrafi ditengarai hadirnya prasasti bercorak khusus, sedangkan dalam studi filologis dikenal lahirnya aksara Buda atau aksara Gunung. Keduanya adalah penyimpangan penulisan dari aksara Jawa Kuna Standar. Perubahan ini juga dijumpai pada inskripsi pendek di Candi Sanggar. Kajian interdisipliner antara filologi dan arkeologi perlu dikembangkan untuk merekonstruksi kebudayaan secara komprehensif. Melalui pendekatan filoarkeologis, ditemukan kedekatan bentuk inskripsi pendek Candi Sanggar dengan aksara-aksara dalam naskah koleksi Merapi-Merbabu. Dalam tulisan ini, disarankan untuk membaca inskripsi pendek tersebut sebagai sengkalan, secara khusus sebagai Sĕngkalan Dihyang. Melalui kaidah sengkalan ini, pembacaan inskripsi tidak lagi dianggap sebagai huruf, tetapi lebih cenderung ke arah angka yang dibaca $\mathbf{7 5}(\mathbf{1}, 3), \mathbf{5 5}(\mathbf{3 , 5})$, 67(3,3), 57(3,2). Sěngkalan Dihyang merupakan sistem penanda waktu dalam masyarakat Jawa Kuna. 
Reinterpretasi Mantra ....(Rendra Agusta)

\section{DAFTAR PUSTAKA}

Ashari, C. (2010). Inskripsi-Inskripsi Pada Relief. Karmawibhangga di Candi Borobudur: Kajian Epigrafi. Universitas Indonesia.

Bleeker, P. (1852). Verzlag der Werkzaamheden van het Bataviaasch Genootschap van Kunsten en Wetenschappen, van September 1850 tot April 1852, namens het Bestuur des Genootschaps Woorgelezen in de Algemeene Vergadering op den 27sten April 1852. Batavia: Verhandelingen Bataviaasch Genootschap.

Boechari. (2012). Melacak Sejarah Kuno Indonesia lewat Prasasti. Jakarta: KPG-EFEO.

Bratakesawa, R. (1980). Keterangan Candrasengkala. Jakarta: Balai Pustaka.

Casparis, J. G. de. (1975). Indonesia Paleography: A History of Writing in Indonesia from the Begininning to c. A.D 1500. Leiden: E.J. BRILL.

Dwiyanto, D. (2018). Refleksi Penelitian Epigrafi dan Prospek Pengembangannya. Yogyakarta: Kepel Press.

Hall, K. R. (1985). Maritim Trade and State Development in Early Southeast Asia. Sidney: Allen \& Unwin.

Hefner, N. S. (1992). Pembaron: An East Javanese Rite of Priestly Rebirth. Journal of Southeast Asian Studies, 267-269.

Istari, T. R. (2006). Arsitektur Candi Sanggar di Lereng Gunung Bromo. Yogyakarta.

Istari, T. R. (2014). Candi di Lereng Bromo. In I. Andrisijanti (Ed.), Majapahit Batas dan Jejak Kejayaan di Luar Kota. Yogyakarta: Kepel Press.

Istari, T. R. (2015). Prasasti Pendek dari Candi Sanggar dan Kemungkinan Penghormatan terhadap Dewa Brahma. Berkala Arkeologi, 5(1), 64.

Kartadiwirya, M. P. (1932). Aanteekeningen over de Tenggereeschen ontvangen can den heer Dr. H. Kraemer. Depok: FSUI.

Kempers, B. (1941). Wat is Archaeologie. In Tijdschrift voor Indische Tall-, Land-, en Volkenkunde (Vol. LXXXI). Batavia: : Koninklijk Bataviaasch Genootschap van Künsten en Wetenschappen.

Kieven, L. (2017). Menelusuri Panji di Candi-Candi: Relief Fgur Bertopi di Candi-candi Zaman Majapahit. Jakarta: KPG-EFEO.

Kriswanto, A. (2012). Gita Sinangsaya. Jakarta: Perpustakaan Nasional RI.

Kurniawan, A. (2017). Mencapai Keselamatan: Tinjauan Awal Pengaruh Islam dalam Skriptoria Merapi-Merbabu Abad 16--18. Jurnal Sejarah, I(1), 1-29.

Lutfi, I. (2015). Epigrafis pada Kawasan Cagar Budaya Penanggungan. In Diskusi Ilmiah Arkeologi 2015 (hal. 7-24). Surabaya: IAAI Komda Jawa Timur.

Martana, I. K. (1990). Arjunawiwāha: Transformasi Teks Jawa Kuna lewat Tanggapan dan Penciptaan di Lingkungan Sastra Jawa. Yoyakarta: Duta Waca University Press. 
PURBAWIDYA: @ Vol 7, No.2, November 2018 137-148

Molen, W. van der. (2011). Kritik Teks Jawa: Sebuah Pemandangan Umum dan Pendekatan Baru yang Diterapkan kepada Kunjarakarna. Jakarta: Yayasan Pustaka Obor Indonesia.

Molen, W. van der, \& Wiryamartana, I. (2001). The Merapi-Merbabu Manuscripts. A Neglected Collection. Bijdragen tot de Taal-, Land-en Volkenkunde, (157), 51-64.

Munandar, A. A. (1990). Kegiatan Keagamaan di Pawitra: Gunung Suci di Jawa Timur Abad 1415. Universitas Indonesia.

Munandar, A. A. (2004). Karya Sastra Jawa Kuno yang Diabadikan pada Relief. Makara Sosio Humaniora, 8(2), 56-60. Diambil dari https://media.neliti.com/media/publications/4366-IDkarya-sastra-jawa-kuno-yang-diabadikan-pada-relief-candi-candi-abad-ke-1315-m.pdf

Munandar, A. A. (2013). Tak Ada Kanal di Majapahit. Jakarta: Wedatama Widya Sastra.

Noorduyn, J. (1982). Bujangga Maniks journeys through Java; topographical data from an old Sundanese source. Bijdragen tot de Taal-, Land-en Volkenkunde, 138(4), 413-442.

Setyawati, K. (1995). Naskah-naskah Merapi-Merbabu Koleksi Perpustakaan Nasional. Humaniora, 37-39.

Setyawati, K. (2015). Kidung Surajaya: suntingan teks, terjemahan dan analisis makna isi teks. Leiden: Universitas Leiden.

Setyawati, K., Molen, W. v., \& Martana, I. W. (2002). Katalog naskah Merapi-Merbabu. Yogyakarta: Universitas Sanata Darma.

Sutrisno, S. (1981). Relevansi Studi Filologi. Pidato Pengukuhan Guru Besar. Yogyakarta: Universitas Gadjah Mada.

Tim Penyusun. (2008). Kamus Besar Bahasa Indonesia. Jakarta: Pusat Bahasa Depatemen Pendidikan Nasional.

Zoetmulder, P. (1994). Kalangwan: Sastra Jawa Kuno Selayang Pandang (Vol. III). Jakarta: Jambatan. 